\title{
Assessment of Drivers of Deforestation and Forest Degradation in Phnom Tbeng Forest Based on Socio-Economic Surveys
}

\author{
Somanta Chan ${ }^{1}$, Nophea Sasaki ${ }^{1,2}$ \\ ${ }^{1}$ Department of Policy and Management Informatics, Graduate School of Applied Informatics, University of \\ Hyogo, Kobe, Japan \\ ${ }^{2}$ School of Earth and Environmental Sciences, University of Adelaide, Adelaide, Australia \\ Email: chan.somanta@gmail.com
}

Received 8 October 2014; revised 5 November 2014; accepted 1 December 2014

Copyright (C) 2014 by authors and Scientific Research Publishing Inc.

This work is licensed under the Creative Commons Attribution International License (CC BY). http://creativecommons.org/licenses/by/4.0/

(c) () Open Access

\begin{abstract}
Carbon emission reductions through reducing deforestation and forest degradation or REDD+ scheme of the United Nations Framework Convention on Climate Change could not be achieved without understanding the drivers of deforestation and forest degradation. Until recently, only a handful of study has focused on such drivers. Cambodia experienced rapid deforestation and forest degradation despite growing international interests in protecting forests for carbon revenue generation. This paper was designed to assess livelihood of forest-dependent community and drivers of deforestation and forest degradation in Cambodia. Quantitative and qualitative methods were used to collect socio-economic data from 42 households living in Phnom Tbeng forest, where annual deforestation rate was about $2.4 \%$ between 2004 and 2009 . Our results suggest that local people depend on forests for income generation, subsistence use and social identity. About $\mathbf{9 0 \%}$ of the respondents believed that deforestation was resulted from illegal logging, slush and burn agricultural practices, land clearing for large plantation, land encroachment, firewood extraction, charcoal production and forest fire. As the population has increased rapidly and almost $100 \%$ of local people depend on fuelwood for cooking, fuelwood collection will continue to cause deforestation and forest degradation unless alternative sources of affordable energy are provided. Appropriate policy interventions should be proposed to reduce the drivers obtained in this study because if drivers cannot be reduced, it is not possible to reduce deforestation and forest degradation, and related carbon emissions.
\end{abstract}

\section{Keywords}

Deforestation, Forest Degradation, Fuelwood Collection, Poverty, REDD+ 


\section{Introduction}

Natural forests are habitat to more than half of terrestrial plant and animal species [1]. In addition to supplying wood and non-wood products, forests provide additional ecosystem services such as recreation and ecotourism [2], erosion control from landslides [3] and wind protection [2], flood protection and benefits to water quality, and climate regulation through carbon sequestration [4] [5]. Forests are the important source of income and subsistence use for rural population [6]. A report by the World Health Organization in 2000 showed that $80 \%$ of the population inhabiting in the developing countries utilized wild products to meet some of their health and nutritional needs [7]. The function of wild products is also well established through the reduction of poor people's vulnerability by satisfying periodic food or income shortages and providing a buffer during difficult times [8]-[10]. However, fast population growth and rapid economic development in tropical countries in the last few decades have put increasing pressure on forests because a large area of forests were being overexploited or cleared for resettlement and agricultural expansion [11]-[14]. Such exploitation and clearing forests have contributed to climate change and adversely impact the livelihood of forest dependent communities [6].

According to the Copenhagen Accord adopted in 2009 at the 15th of the Conference of the Parties to the United Nation Framework Convention on Climate Change, climate change is one of the greatest challenges of our time and a deep cut in global greenhouse gas emissions is required to deal with this problem [15]. The Copenhagen Accord also recognizes the crucial role of reducing emissions from deforestation and forest degradation, forest conservation, sustainable management of forests, enhancement of forest carbon stocks in developing countries or commonly known as REDD+. REDD+ is a financial scheme to reward project activities that result in reducing carbon emissions from deforestation and forest degradation while also improving livelihood of local people. Asia \& Europe are important partners in the global efforts to reducing carbon emissions.

Cambodia is one of the most vulnerable countries to climate change in the region [16]-[18]. Climate change already became apparent in Cambodia as indicated by the rising of temperature and erratic rainfall pattern since 1960s and continued to change until recently [18] [19]. This change will affect main sectors of Cambodia economy such as agriculture, health, and fishery, particularly in forestry. In the late 1960s, forest cover in Cambodia was 13.2 million hectares or 73\% of total land area [20] and it have undergone a substantial decline from 13.2 million hectares in 1970 to 10.4 million hectares in 2010 [21] [22] due to civil war, population growth, poverty and internal migration. Recent study revealed that annual deforestation rate in 1973-2003 was 0.7\% [23] and 0.8\% between 2002 and 2010 [22] [24] suggesting that Cambodian forest cover was still declining at alarming rate. Therefore, there is an urgent need to reduce the loss of forest cover, and if done appropriately, Cambodia can benefit from the REDD+ scheme. However, emission reductions could be achieved, only if appropriate intervention policies to reduce drivers of deforestation and forest degradation can be introduced [25]. How to balance between forest conservation and rural economic development has become a major issue. Socio-economic surveys are important methods used to access local livelihood and causes of deforestation and forest degradation [26] [27]. The assessment will define the drivers of deforestation and forest degradation that are the causes, to which appropriate interventions can be introduced.

European Union is Cambodia's important partner supporting forest protection and sustainable development through its financial and humanitarian aid. European countries and their agencies have assisted Cambodia in terms of financial support and establishing platform to manage forests for long-term benefits in forest dependent communities. DANIDA of Denmark has contributed to climate change and forestry assessment in Cambodia. Oxfam Great Britain provided funding for establishment of forest community called "Chamkar Koki forest community” located in Svay Rieng Province, while German Development Corporation and Belgium Government respectively funded the establishment of "Trapang Sdao forest community" in Kompot Province and “Dangpnao forest community” in Siem Reap Province [28]. With this establishment, forest-dependent communities can derive benefits from forest and non-forest products as income source and subsistence use. Furthermore, a REDD+ Carbon Project was developed in the Seima Protected Forest in Mondulkiri Province with the support of the Wildlife Conservation Society (WCS) in 2009.

Although previous studies and project assistance from EU countries provide fundamental understanding of international interests in protecting tropical forests and forests' contribution to rural development, achieving deforestation and forest degradation reduction requires understanding of local perception in respect to socio-economic values derived from forests. Using quantitative and qualitative data from field surveys, this study attempted to assess how local people value the forests economically and socially, and their perception toward 
drivers of deforestation and forest degradation. This study would be useful for introducing appropriate policies that could result in forest protection and sustainable development in Cambodia.

\section{Study Method and Materials}

\subsection{Site Selection}

Understanding socio-economic values of forests in Cambodia are important for designing appropriate interventions which less harm to local communities' livelihood and contribute to reducing carbon emissions from deforestation and forest degradation in Cambodia. Field survey was conducted in late 2011 in five villages: 1) Mohaphal village; 2) Boeung village; 3) Dar village; 4) Srei Sronos village and 5) Srobal village adjacent to Phnom Tbeng forest of Preah Vihear Province, Cambodia. Total area of Phnom Tbeng forest is about 41,038 ha comprising four types of forest, namely evergreen, semi-evergreen, deciduous and other forests (Figure 1). This forest is located at 100 to $530 \mathrm{~m}$ elevation above sea level and it has plateau geography. Edges of the plateau are very steep but it is flat on top of the plateau. Semi-evergreen forest in the steep slopes of the edge is distributed mainly to be dominant, while in the flat land on the top of the plateau, evergreen forest is dominant. There are approximately 9700 families living in the communes in the study site [29].

\subsection{Forest Cover Change in Phnom Tbeng Forest}

According to data analysis by Forest Technology Association (JAFTA), total forest area in this study site decreased from 41,530 ha in 2004 to 41,038 ha in 2009 with an annual decrease rate of 0.24\% (JAFTA's unpublished data). More specifically, evergreen forest decreased $2.71 \%$, semi-evergreen forest $2.09 \%$, and other

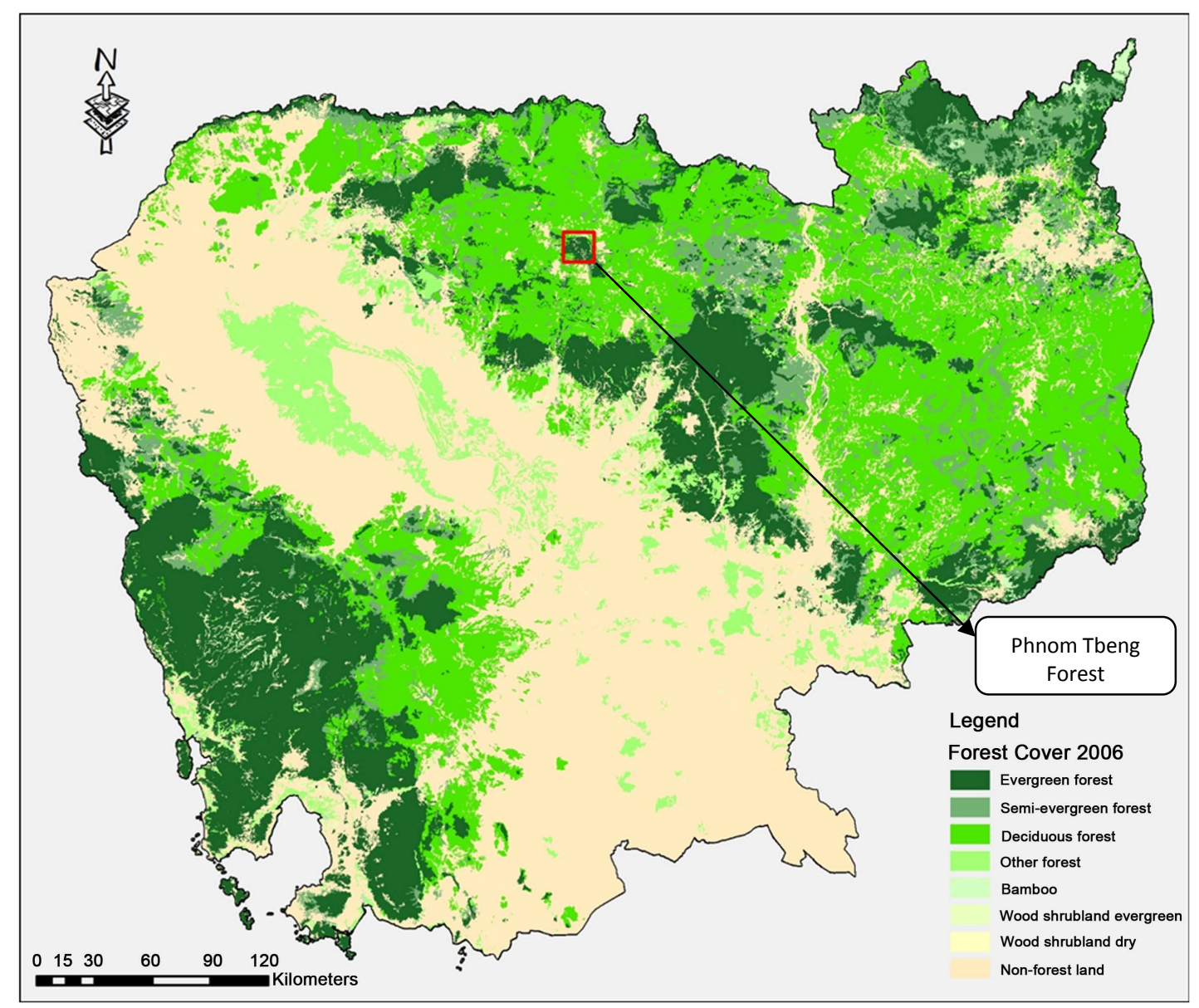

Figure 1. Location of Phnom Tbeng forest. 
forests $1.53 \%$. In contrast, deciduous forest has increased 5.58\% from 10,954 ha to 14,013 ha annually over the same period between 2004 and 2009 (Table 1).

\subsection{Data Collection}

Both qualitative and quantitative methods were employed for collecting primary data from the target villages of the study. The data collection was taken from 14 to 18 December 2011. Three focus group discussions were conducted with representatives from different communes, village chiefs and commune councils in the districts around Phnom Tbeng area. They were stakeholders (37 people) commune councils, village chiefs and key villagers (28 people) (Table 2). There were two exercises carried out in the focus group discussion included stakeholder analysis and problem analysis. The purpose of stakeholders' analysis was to identify and understand the issues, problems and current conditions of the study area by analyzing people living in the area and its vicinity, related groups, and the organizations and associated agencies, and to identify the target group of the project. Problem analysis was applied to sort out existing problems in the area and sector based on a cause and effect relationship and then visualizes those problems in an easy-to-understand diagram, named as Problem Tree. At the village level five key informant meetings were held to generate village landscapes, land use, forest dependency, agriculture and socio-economic information. The village chief and villagers' representatives preferably the ones who are more knowledgeable about the area were invited to take part in the meeting. The numbers of participants in each meeting were from 4 to 8 people. In addition, a household survey on socio-economic, forest dependency of the household, awareness and potential compensation measure to mitigate forest clearance was carried as a supplement to the above participatory rural appraisal exercises. The main objective of the survey was to understand the local dependency on forests. The content of this questionnaires included general information of the respondent's household, their dependency on forest for their livelihoods, level of awareness about forest use and management, the compensation to their forest dependency and drivers of deforestation and forest degradation. Totally, 42 households were randomly selected from the villages around Phnom Tbeng as sample for this survey.

Table 1. Forest cover changes by forest types in Phnom Tbeng forest 2004-2009.

\begin{tabular}{cccccc}
\hline \multirow{2}{*}{ Forest type } & \multicolumn{2}{c}{$\mathbf{2 0 0 4}$} & \multicolumn{2}{c}{$\mathbf{2 0 0 9}$} & $\begin{array}{c}\text { Annual change rate } \\
\text { 2004-2009 }\end{array}$ \\
\cline { 2 - 6 } Evergreen & Area (ha) & Percent & Area (ha) & Percent & $-2.71 \%$ \\
\hline Semi-evergreen & 14,784 & $34.3 \%$ & 12,778 & $29.7 \%$ & $-2.09 \%$ \\
Deciduous & 12,075 & $28.1 \%$ & 10,816 & $25.1 \%$ & $5.58 \%$ \\
Other forests & 10,954 & $25.5 \%$ & 14,013 & $32.6 \%$ & $-1.53 \%$ \\
Total forest & 3,716 & $8.6 \%$ & 3431 & $8.0 \%$ & $-0.24 \%$ \\
None forest & 41,529 & $96.5 \%$ & 41,038 & $95.3 \%$ & $6.51 \%$ \\
Total area & 1512 & $3.5 \%$ & 2003 & $4.7 \%$ & - \\
\hline
\end{tabular}

Table 2. Number of stakeholder and households surveyed.

\begin{tabular}{cccc} 
Field exercise & Male & Female & Total \\
\hline Stakeholder and problem analysis of Phnom Tbeng forest & 29 people & 8 people & 37 people \\
Village key informant meeting & 16 people & 12 people & 28 people \\
Household survey & 12 people & 30 people & 42 people \\
Total & 57 people & 50 people & 107 people \\
\hline
\end{tabular}




\subsection{Data Analysis}

Data obtained from focus group discussions was mainly qualitative in nature. Analysis mainly relied on qualitative data analysis approach included summarizing, categorizing and connecting data. For instance, data on drivers of deforestation and forest degradation in Phnom Tbeng area obtained from the focus group discussion were classified into a few main categories and detail description of each driver and its relation to others was provided. Household survey data, on other hand, was highly quantitative. Analysis of this household survey data is largely based on statistical tools and procedures. SPSS software was employed for this analysis.

\section{Results}

\subsection{General Characteristic of Study Site}

Almost all 9700 households around Phnom Tbeng in Preah Vihear Province are farmers who depend entirely on agriculture and forest resources for living. Population has increased about 6.3\% annually from 2007 to 2010 [30]. Education services are generally improved but data limitation suggests that percentage of children (age 6 - 11) attending school varied from one commune to another. School attendance rate ranges from less than $1 \%$ in Pong Ro commune to more than $50 \%$ in the rest of communes.

The main occupation of villagers in the entire village is farming followed by collection of forest and nonforest products. The highest educational level is in high school. No health center was found in the studied villages but there were few mobile doctors available for treating villagers in various locations. Rainfall is the only source of water for their farming because irrigation system is very poor in the villages. Water supply for household consumption comes from well. Some villagers can access to battery light as source of their electricity because electricity grid is still unavailable. Infrastructure has been gradually developed for most of the villages in terms of physical access to the village, except in Srei Sronos village where accessible road is not available. Accessibility to Srei Sronos village is possible only through paddy field. The houses in each of village are traditionally built close to each other. This practice is still adopted for security and social reasons of the villagers.

Each household owns cropping land (from 2 - 5 ha) except in Srobal village where most of the families own less than 2 ha of land. None of families in the five villages own more than 5 ha of cropping land. Official land title for agricultural land in this area was not yet granted by the central government and this practice is still common in other parts of Cambodia. Farmers in the studied villages and in neighboring villages obtained their legitimate land tenure from the local authorities i.e. village chief and commune councils. Official tenure is not yet a concern of the villagers since villagers mutually recognize their respective lands and protect their lands from outsiders. It is also possible for villagers to sell their land to others with recognition by village or commune level. The most important agricultural product is rice with average annual yield of $1000 \mathrm{~kg} / \mathrm{ha}$ to $3000 \mathrm{~kg} / \mathrm{ha}$, which are the range of average yield in Cambodia (1980 kg/ha) but lower than that in other countries in region [31].

Cattles (cow and buffalo) are main source of agricultural labor in most villages although some households use plowing machines. In general, the majority of the villagers have livestock such as pig, chicken and duck are in addition to cow and buffalo. On average, a family has 2 - 3 pigs or 5 - 8 chickens or 8 - 10 ducks. In terms of cattle, each family owns about 2 - 3 animals and they are main force for plowing the paddy field, transporting rice and performing other labor-intensive tasks. Meat from the livestock products is used for household consumption as food and in some cases, for sale. Livestock production in Cambodia accounted for 4.6\% of GDP in 2006 [32] and was the second most important source of protein intake after fish in Cambodia.

\subsection{Household Survey}

\subsubsection{Family Information}

We presented results from quantitative surveys on 42 households randomly selected around Phnom Tbeng area. Respondents' age ranges from 15 to 70 years old with an average of 40 years old. About $83 \%$ of the respondents are either father or mother in their families, $5 \%, 12 \%$ are grandparent and child respectively (Table 3). About $74 \%$ of the respondents were born in the visited villages while the rest (26\% of the respondents) born in different places, which is termed here as migrant. The main reasons of these migrants were to seek for new livelihood opportunity or bring their spouse to live together in the village. These migrants are the agent of deforestation and forest degradation because they harvested the forests for housing and sales for income generation. An open 
Table 3. Relation of respondents in family.

\begin{tabular}{ccccc}
\hline Father & Mother & Child & Grand parent & Total \\
\hline 10 & 25 & 5 & 2 & 42 \\
$24 \%$ & $59 \%$ & $12 \%$ & $5 \%$ & $100 \%$ \\
\hline
\end{tabular}

access of this forest has let them to clear forests for settlement and plantation, despite land tenures were not recognized by authorities and local people. This practice has caused concern to local people because migrants indiscriminately cleared and burned land of local people for slush and burn cultivation.

As shown in Table 4, the average members in each family are 5.2 members ranging from 2 to 9 members for all ages. Specifically for family with age greater than 15 years old, average members are 3.5 with minimum and maximum of 2 - 6 members, respectively. The minimum family members of the respondents are 2 people and the maximum is 9 people. For people aged over 15 year old the range is from 2 to 6 people each family. Only about 2 members, on average per family are considered as literate for their ability to understand, read, and write Cambodian language. Almost 100\% of villagers having children aged from 6 to 15 years old replied that their children attended school. The highest level of education amongst the respondents is high school.

\subsubsection{Household Asset}

Average size of the house of the respondents is $43.14 \mathrm{~m}^{2}$ ranging from $12 \mathrm{~m}^{2}$ to $70 \mathrm{~m}^{2}$. About $90 \%$ of house's walls are made of wood followed by thatch (5\%) and bamboo (5\%). About three-fourth of the respondents live in the house with zinc roof, another $19 \%$ with thatch roof and the rest $5 \%$ are roof made of fibro (Table 5). This information indicated that forest is an important source of materials for housing. Overexploitation of forests for housing is likely to occur for many years since the demand of wood locally have dramatically increased by population growth and the shortage of wood supply from neighboring countries.

\subsubsection{Sources of Livelihoods}

The results suggested that main livelihood sources of villagers are forest product, laboring, cropping, livestock and fishing. We assessed these sources of livelihood with the following quote: very important, important, little important, not important and don't know. Since community is not homogenous, family has different sources of livelihoods, some of which are important while others are not so important. As seen in Figure 2, forest products were viewed as very important or important by about $85 \%$ of respondents since forest products have been extracted for subsistence and cash income, followed by laboring at about $80 \%$ of respondents because they also relied on works from agricultural sector and logging services. This also illustrates that forests play a very crucial part to livelihoods of this people since they provide employment opportunities and forest products. Almost one third of the respondents, livestock are very important for them as they help farming work, provide food and some cases for sale. In general, the four sources (cropping, livestock, forest products, and laboring) of livelihoods listed in the questions are important for most of the respondents (80\%). Fishing is not viewed as important for livelihoods due to a couple of reasons. The first reason is the natural endowment of this region is not potential for fishing. Secondly, other sources, timber or laboring are more attractive and accessible to villagers.

\subsubsection{Contribution of Forest Products to Household Livelihoods}

Generally forest products can provide both subsistence and cash income to households. Our surveys suggested that forest and non-forest products were extracted include firewood, timber for construction, resin tapping, rubber, wild meat, fruits/vegetables, rattan, medical plants and fishing ground. The Figure 3 showed the variety of forest and non-forest products and their perceived importance to local people. The first important product from the forest was firewood ( $77 \%$ of respondents), timber for construction (20\% of the respondents) and medical plants (3\% of respondents). The products come to second, third and fourth important are rubber, rattan, resin tapping, fruits/vegetables, fishing ground and wild meat (Figure 3). A study in Bangladesh revealed that contribution of forest to household livelihood is timber, firewood and wild NTFPs (bamboo, wild vegetables, sun grass, broom grass, game meat, bamboo shoots, medical plants and wild fruits). Most three important wild NTFPs for sale are bamboo, wild vegetables and broom grass with mean annual income from NTFPs was US \$69.01 [33] while NTFPs for sale in Cambodia are resins, honey and beeswax (US \$78.9) [34]. Potential 


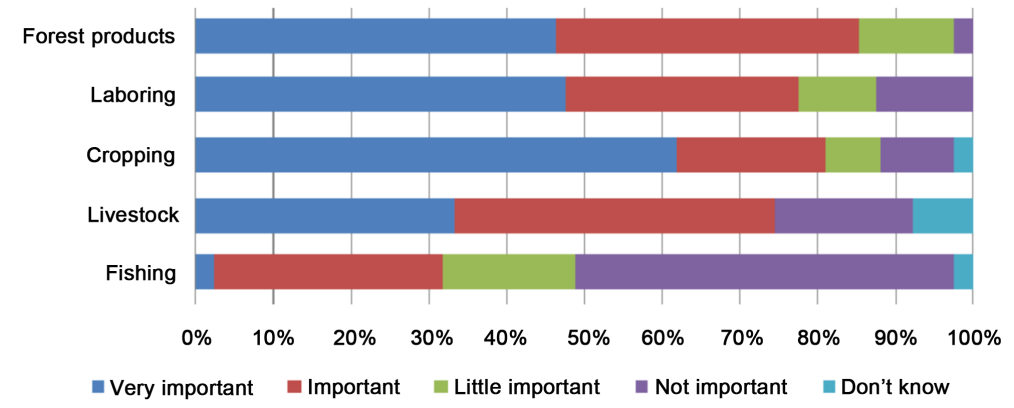

Figure 2. Main livelihood sources of villagers.

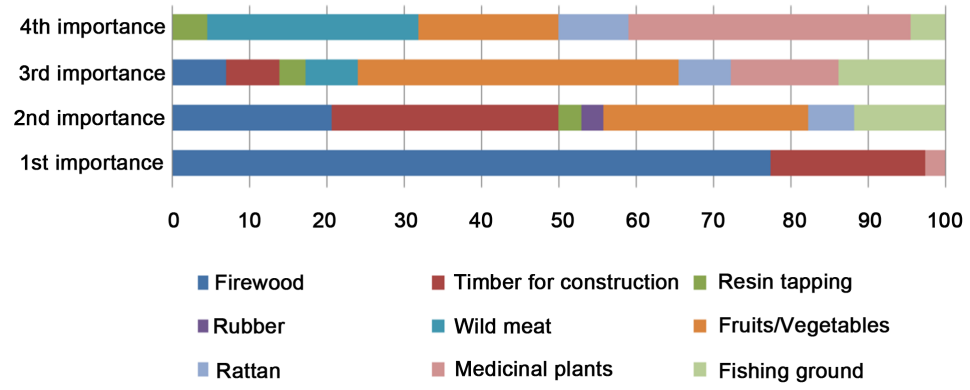

Figure 3. Important of different forest products to household livelihood.

Table 4. Family member of respondents.

\begin{tabular}{ccccc}
\hline Family members of respondent & Minimum & Maximum & Mean & Standard deviation \\
\hline Total family member & 2 & 9 & 5.2 & 1.8 \\
Member aged above 15 & 2 & 6 & 3.5 & 1.5 \\
Member aged above 15 who is literate & 0 & 6 & 2.2 & 1.6 \\
\hline
\end{tabular}

Table 5. Housing materials.
\begin{tabular}{cccccc}
\hline \multicolumn{1}{c}{ Wall } & & \multicolumn{4}{c}{ Roof } \\
\hline Wood & Bamboo & Thatch & Zinc & Thatch/leaves & Fibro \\
$90 \%$ & $5 \%$ & $5 \%$ & $76 \%$ & $19 \%$ & $5 \%$ \\
\hline
\end{tabular}

source of income in Cambodia derives from NTFPs are higher than in Bangladesh because villagers in Bangladesh depend more on daily wage labor (usually temporary or seasonal), and they collect NTFPs only when they don't have any wage labor in agriculture or another employment. Although this value is small but it represents amount of villagers' extra money. Moreover, most of the respondents also stated that forest doesn't only mean to livelihood but their social and cultural identity as well. Several studies were reported that poor households in tropic depend on forest resources [35]-[39], thus if forests are still being deforested or degraded, it will put livelihood of local people at risk since a proportion of income and subsistence is related to forest-based activities.

\subsubsection{Identification of Drivers of Deforestation and Forest Degradation}

We designed questionnaires to ask respondents to rate their perception toward current drivers of deforestation and forest degradation. The survey reveals that more than haft of the respondents (57\%) used to cleared forest and some cases were taken place in recent year in average the size 1.2 ha per villagers. As trust between research team and respondents are limited because this is a sensitive question related to illegal logging. Therefore the cases of clearing forest may even be higher than this figure. As seen in Figure 4 the main cause of deforestation 


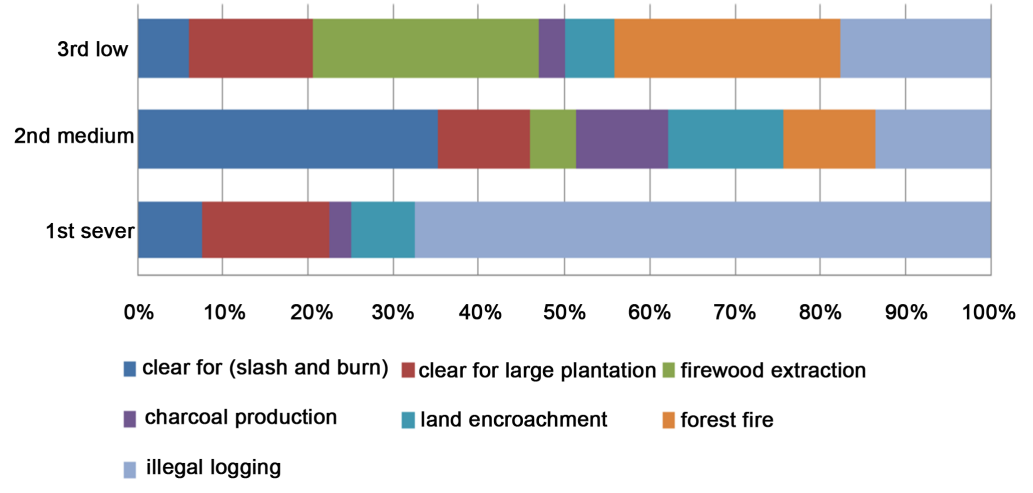

Figure 4. Drivers of deforestation and forest degradation.

given by majority of the respondents is illegal logging (almost 70\%) because of rapid increase in market demand of commercial timber, timber for house construction and firewood. Due to the inefficient of agriculture productivity, limited access to technology and seeking potential of agro-industrial, people need more land to cultivate their agriculture by clearing more forests for slush and burn cultivation and large plantation. In addition, the increasing in number of migrants and land speculation, forests are felled down to claim land for settlement and then would be later possible to be sold. There is not a serious problem to forest cause by forest fire as only $10 \%$ of the respondents mentioned forest fire to be second cause (Figure 4). This also confirms from data in village key informant as forest fire is rarely occur in the Phnom Tbeng area. Logging for commercial purposes is compounded by local demands for house construction and fuelwood consumption severely threat the Phnom Tbeng forest. There is no rule of management system established to regulate the use and access to forest of villagers in each of the visited villages. Phnom Tbeng forest is seen as common resources where everyone can access to and freely benefit from it. This situation of an open access encourages competition amongst different users rather than cooperation and lead to destruction practices.

More specifically, based on data analysis drivers of deforestation and forest degradation are classified into illegal logging/timber extraction, forest clearing for large plantation, forest clearing for slush \& burn, land encroachment, charcoal production, firewood extraction, and forest fire. The underlying causes for these drivers include limited livelihood options, weak implementation of the law, political instability and poor forestry governance. Ty et al. [25] assessed and clarified 10 drivers of deforestation in Oddar Meanchey Province, namely forest clearing for sales $30 \%$, conversion to cropland $30 \%$, conversion to settlements $10 \%$, fuel-wood gathering $10 \%$, forest fired induced to clean land $5 \%$, hunting inducing forest fires $5 \%$, illegal logging for commercial on sale $5 \%$, timber harvesting for local use 5\%, large economic land concessions and timber concession with a very small proportion. To reduce such drivers, any appropriate intervention requires specific assessment in place since its drivers are varied and complicated.

\section{Discussion}

\subsection{Project Action and Compensation to Avoid Deforestation}

This study identified seven drivers of deforestation and forest degradation, namely illegal logging and timber extraction, forest clearing for large plantation, forest clearing for slush and burn, land encroachment, charcoal production, firewood extraction, and forest fire. These drivers may be reduced by introduction of appropriate project actions such as forest-patrolling, agricultural intensification, law enforcement, new job opportunity development, introducing new sources of energy consumption, cattle protection against insects and fire prevention. Unlike in Oddar Meanchey Province where there are 10 drivers [25], forest clearing for sales, large economic land concessions and timber concession did not occur in the study site. Reducing these drivers will contribute to reducing deforestation and forest degradation, and therefore reducing carbon emissions. Ty et al. [25] proposed 10 project actions to reduce drivers of deforestation and forest degradation in the Northern Province, such as strengthening land tenure, land-use plans, forest protection, assisted natural regeneration, introduction of fuelefficient stoves, introduction of mosquito nets, agricultural intensification, water resource development project, NTFPs development and fire prevention. However, strengthening land tenure currently is not necessary for this 
study region since land title was officially recognized at commune level. Such recognition can entitle villagers to farm on or even sell their land. However in the future as land migrants are increasing, land title recognized by the central government should be issued to avoid conflict and destruction of forest resources. Introduction of fuel-efficient stoves is important in this area because firewood is being negligibly used and introducing such stoves will reduce the felling of trees for firewood production and for charcoal making. Agricultural intensification can increase yield of their cultivated land through labor, fertilizers, new irrigation system and technological changes without expanding their land or clearing more forest land. Technology changes and new corn varieties have been employed in Vietnam in 1990s that allowed corn yields to triple within a few years [40]. Since NTFPs have ensured food security and income earning to rural populations [41], NTFPs development should be promoted by facilitating the access to markets and increasing NTFPs prices, better collection methods, capacity development and financial support. On another hand, creating potential job opportunities at local level such as through ecotourism or enterprise development would provide additional source of income, which eventually can make villagers less dependent of forest resources. In 2000, Honghe Prefecture government of China has developed forest dependent communities in Qingkou as eco-cultural tourism village. About US \$500,000 was invested to improve Quingkou's infrastructure and facilities. Tourism revenue is derived from entry tickets and cultural performances, 30\% of which distributed among household living in Quingkou [42]. Furthermore local people are able to benefit from serving as tour guides, providing services for camping sites and selling forest and non-forest products.

Based on our study, high dependency of Phnom Tbeng people on the forests may reduce the carrying capacity of the ecosystem, which could lead to forest degradation if no adequate management measures are put in place. Alongside a participatory forest management plan as a prerequisite of forest resource governance, empowerment of the local community in forest conservation is also critical. Based on our survey, majority of the respondents would be willing to take part in forest patrolling and only a minor proportion of the respondents did not agree to participate as they thought it is already late to start the initiative of forest protection in Phnom Tbeng. We further interviewed them whether they would participate in forest protection if there is a financial compensation scheme available to do so. Surprisingly, $45 \%$ of the respondents prefer cash as compensation, $20 \%$ prefer agricultural education, while the rest prefer assistance in terms of access to better markets for their agricultural products. Providing pesticide and fertilizer, education facility, health service and social land concession obtained similar proportion of respondents' preferences in general (Figure 5).

\subsection{Limitation of the Study}

Aptitudes of the respondents, pressure and timing of the interviews could affect the results of our study because deforestation and forest degradation are a very sensitive issue in Cambodia. Trust between the interviewers and respondents are important. Some sensitive questions such as "have you ever cleared forest?" are difficult to get the appropriate answer because it may make them feel guilty. Koy and Sasaki [43] recommended that seasonal survey would provide results with less biases because local people tends to respond according to their recent memory and seasonal variation. Another limitation is the lack of reference relating to traditional uses of forests in the study site because many development projects in the area have been focusing mainly on health, education or sanitation. Future works should include seasonal surveys with less sensitive questions.

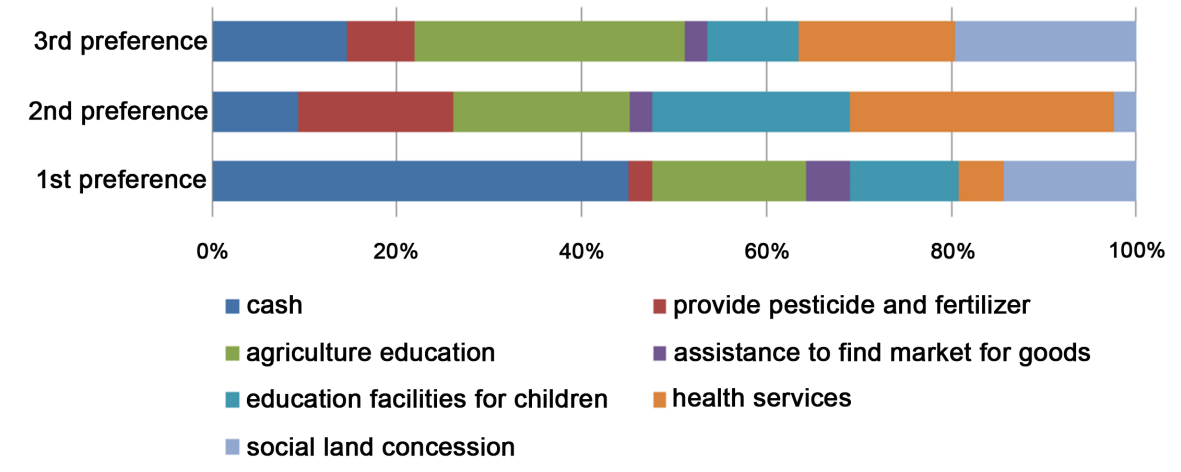

Figure 5. Preferred compensation to participate in forest protection. 


\section{Framework to Reducing Drivers of Deforestation and Forest Degradation}

Food and energy security are important for poverty alleviation. Reducing poverty is a crucial step to be taken in order to reduce drivers of deforestation and forest degradation. Based on our survey, these communities are favorable to improve their livelihoods through farm production of harvesting wild products, adding value to forest products, improving their marketing or shifting to off-farm activities. However, there are many significant constraints based on discussions with communities, key issues in farming sector include: 1) low availability of information on improved farming techniques that are appropriate to the agro-ecological conditions of Phnom Tbeng forest; 2) lack of land tenure or title discouraging investment; 3) subsistence farmers have limited ability to take risks or experiments with new crops (including cash crops); 4) poor access to water, including lack of irrigation systems in paddy field rice growing area; 5) marketing difficulties and trade monopolies due to the poor road network. If the opportunities listed above could be targeted in a timely and wisely fashion, we can improve living standard of local communities, which would eventually lead to reducing deforestation and forest degradation in Phnom Tbeng forest.

Survey results also showed that besides from forest products and cropping, most of people in Phnom Tbeng area depend only on laboring in agriculture and logging services for daily subsistence. Thus creating job opportunities at local level such as through ecotourism, factory or enterprise development could also bring additional income to local people [44]-[49]. In 2000, Qingkou forest dependent communities in China has been developed as eco-cultural tourism village where local people can earn from entry tickets, cultural performances, guiding services, renting camping sites and selling forest and non-products [42]. Another problem of rural poor is the lack of energy. Currently, firewood is the only source of daily cooking energy. Energy from power grid is not possible. Even if it is possible, the price is more than 5 times higher than that is the city. Our survey suggests that approximately $80 \%$ of local people viewed firewood as an important source of energy. Providing alternative affordable energy could have great implications on firewood extraction. As seen in some parts of Cambodia, New Lao Stove has been designed by Groupe Energies Renouvelables, Environnement et Solidarités to replace traditional cooking stove which can save up to $21.2 \%$ on charcoal and $20.89 \%$ on wood [50]. For rural smallholders, small-scale biogas production is one of the most attractive alternatives widely used in India and China [51] where biogas is generated from their agriculture residues and livestock dung. Biogas has also proved to be one of the most promising renewable energy technologies for rural areas of Nepal, where cooking and lighting are the most important uses of biogas [52].

\section{Conclusion}

Quantitative and qualitative methods were used for this study to assess socio-economic condition of local people, their dependency on forest and explore drivers of deforestation and forest degradation. The team carried out fieldwork at three levels. First level was discussions with selected commune and village representatives to identify the drivers of deforestation and forest degradation. Second level was a key informant meeting to generate village landscape, land use and socio-economic information. Third level was a quantitative survey of 42 households randomly selected within difference villages to uncover their dependency on forest for their livelihoods and their compensation preference for keeping forest. The total number of people the team met in three types of field works was 107 people (female: 50). The results indicated that major source of their livelihood was farming followed closely by forest and non-forest product and laboring. Forest and non-forest products provided both income and subsistence to local people such as firewood, timber for construction, resin tapping, rubber, wild meat, fruits/vegetables, rattan, medical plants and fishing ground. Simultaneously, forest is under pressure of deforestation and forest degradation. Illegal logging was seen to be most serious drivers of deforestation and forest degradation followed by forest clearing for large plantation, forest clearing for slush \& burn, land encroachment, charcoal production, firewood extraction, and forest fire. Such drivers should be reduced by appropriate project actions such as forest-patrolling, agricultural intensification, law enforcement, new job opportunity development, introducing new sources of energy consumption, cattle protection against insects and fire prevention. Based on the survey, most people prefer cash, agriculture education, social land concession and education facilities for children as compensation for keeping forest. Since forest-adjacent communities in study site are poor and depend mostly on forest resources to a great extent, thus any forest-based development interventions should be designed to improve livelihoods and facilitate NTFPs as priority. 


\section{Acknowledgements}

Authors would like to thank JAFTA for allowing us to use the data. Hou Kalyan and her team were also thanked for fieldwork assistance and data analysis. This study was partially supported by a Grant-in-Aid for Scientific Research (No. 18402003) from the Ministry of Education, Culture, Sports, Science and Technology of Japan.

\section{References}

[1] Hassan, R.M., Scholes, R. and Ash, N. (2005) Ecosystems and Human Well-Being: Current State and Trends: Findings of the Condition and Trends Working Group of the Millennium Ecosystem Assessment. Island Press, Washington DC.

[2] Evans, J. (2009) The Multiple Roles of Planted Forest. In: Evans, J., Ed., Planted Forest: Uses, Impacts and Sustainability, CAB International and FAO, 61-90.

[3] Dymond, J.R., Ausseil, A.G., Shepherd, J.D. and Buettner, L. (2006) Validation of a Region-Wide Model of Land Slide Susceptibility in the Manawatu-Wanganui Region of New Zealand. Geomorphology, 74, 70-79. http://dx.doi.org/10.1016/j.geomorph.2005.08.005

[4] Carnus, J.M., Parrotta, J., Brockerhoff, E.G., Arbez, M., Jactel, H., Kremer, A., Lamb, D., O’Hara, K. and Walters, B. (2003) Planted Forests and Biodiversity. IUFRO Occasional Paper, 31-50.

[5] Rudel, T.K., Coomes, O.T., Moran, E., Achard, F., Angelsen, A., Xu, J.C. and Lambin, E. (2005) Forest Transitions: Towards a Global Understanding of Land Use Change. Global Environment Change, 15, 23-31. http://dx.doi.org/10.1016/j.gloenvcha.2004.11.001

[6] Food and Agriculture Organization of the United Nations (2006) Better Forestry, Less Poverty: A Practitioner's Guide.

[7] Muzayen, S.F. (2009) The Role of Non-Timber Forest Products to Rural Livelihoods and Forest Conservation: A Case Study at Harana Bulluk District Oromia National Regional State, Ethiopia. M.Sc. Thesis, Wondo Genet College of Forestry and Natural Resources, Wondo Genet.

[8] Ruíz Pérez, M. (1995) A Conceptual Framework for CIFOR’s Research on Non-Wood Forest Products, CIFOR Working Paper No. 6. CIFOR, Bogor.

[9] World Bank (2001) A Revised Forest Strategy for the World Bank Group. Technical Report, World Bank, Washington DC.

[10] Shackleton, C.M. and Shackleton, S.E. (2004) The Importance of Non-Timber Forest Products in Rural Livelihood Security and as Safety Nets: A Review of Evidence from South Africa. South African Journal of Science, 100, 658664.

[11] Kaimowitz, D. and Angelsen, A. (1998) Economic Model for Tropical Deforestation. Center for International Forestry Research, Bogor.

[12] Geist, H.J. and Lambin, E. (2001) What Drives Tropical Deforestation? A Meta-Analysis of Proximate and Underlying Causes of Deforestation Based on Subnational Case Study Evidence. LUCC Report Series 4, CIACO, Louvain-laNeuve.

[13] Revington, J. (1992) The Causes of Tropical Deforestation. New Renaissance Magazine, 3.

[14] Food and Agriculture Organization (2003) State of the World's Forest 2001. Rome.

[15] United Nations Framework Convention on Climate Change (2009) Copenhagen Accord.

[16] Yusuf, A.A. and Francisco, H. (2009) Climate Change Vulnerability Mapping of Southeast Asia. Technical Report, Economy and Environment Program for Southeast Asia.

[17] Bradley, A. (2011) Review of Cambodia REDD’s Readiness: Progress and Challenges. Institute of Global Environmental Strategy (IGES), Japan.

[18] Tin, P. (2011) Key Findings of the Cambodia’s Second National Communication. Presentation Given in 2nd National Forum on Climate Change in Cambodia, Phnom Pen.

[19] La, M. and Ronald, W.J. (2001) Gendered Perspective on Adaptive Behavior of Fishing Households: Effects of Climate Change in Steung Treng. The Learning Institute, Phnom Penh.

[20] Tran, T.C. and Kol, T. (1987) Forest Soil and Vegetable in Cambodia. Department of Forestry and Wildlife, Phnom Penh.

[21] Department of Forestry and Wildlife (1998) Forest Covers Statistics in Cambodia. Department of Forestry and Wildlife, Phnom Penh.

[22] Forestry Administration (2011) Forest Cover Statistics in Cambodia 2002-2010. Forestry Administration, Phnom Penh.

[23] Sasaki, N. (2006) Carbon Emissions Due to Land-Use and Logging in Cambodia-A Modeling Approach. Journal of Forest Research, 11, 397-403. http://dx.doi.org/10.1007/s10310-006-0228-5 
[24] Sasaki, N., Abe, S., Khun, V., Chan, S., Ninomiya, H. and Chheng, K. (2013) Reducing Carbon Emissions through Improved Forest Management in Cambodia. Low Carbon Economy, 4, 55-67.

[25] Ty, S., Sasaki, N., Ahmad, A.H. and Ahmad, Z.A. (2011) REDD Development in Cambodia-Potential Carbon Emission Reductions in a REDD Project. Formath, 10, 1-23.

[26] Inoue, M. (1992) Basic Forest Conservation Policy Based on the Distinctive Feature of Forest Utilization Patterns in the Tropics. Review of Forestry Culture, 13, 27-32.

[27] Nagata, S., Inoue, M. and Oka, H. (1994) The Utility and Regeneration of Forest Resources. Rural Culture Association, Japanese.

[28] Forestry Administration (2006) Forest Cover Statistics in Cambodia. Forestry Administration, Phnom Penh.

[29] The National Committee for Sub-National Democratic Development (2009) Preah Vihear Province Data Book. Cambodia.

[30] The National Committee for Sub-National Democratic Development (2010) Online Commune Database.

[31] United Nation Development Program (2007) Human Development Reports Data for 2004.

[32] National Institute of Statistics (2007) National Accounts of Cambodia 1993-2006. Cambodia.

[33] Kar, S.P. and Jacobson, M.G. (2012) NTFP Income Contribution to Household Economy and Related Socio-Economic Factors: Lessons from Bangladesh. Forest Policy and Economics, 14, 136-142. http://dx.doi.org/10.1016/j.forpol.2011.08.003

[34] Kim, S., Sasaki, N. and Koike, M. (2008) Assessment of Non-Timber Forest Products in Phnom Kok Community Forest, Cambodia. Asia Europe Journal, 6, 345-354.

[35] Arnold, J.E.M. and Ruiz Pérez, M. (2001) Can Non-Timber Forest Products Match Tropical Forest Conservation and Development Objectives? Ecological Economics, 39, 437-447. http://dx.doi.org/10.1016/S0921-8009(01)00236-1

[36] de Beer, J.H. and McDermott, M.J. (1996) The Economic Value of Non-Timber Forest Production Southeast Asia. 2nd Edition, Netherlands Committee for IUCN, Amsterdam.

[37] Belcher, B. and Schreckenberg, K. (2007) Commercialization of Non-Timber Forest Products: A Reality Check. Development Policy Review, 25, 355-377. http://dx.doi.org/10.1111/j.1467-7679.2007.00374.x

[38] Fu, Y., Chen, J., Guo, H., Chen, A., Cui, J. and Hu, H. (2009) The Role of Non-Timber Forest Products during Agroecosystem Shift in Xishuangbanna, Southwestern China. Forest Policy and Economics, 11, 18-25. http://dx.doi.org/10.1016/j.forpol.2008.08.003

[39] Pimentel, D., Mcnair, M., Buck, L., Pimentel, M. and Kamil, J. (1997) The Value of Forests to World Food Security. Human Ecology, 25, 91-120. http://dx.doi.org/10.1023/A:1021987920278

[40] Sikor, T. (2001) The Allocation of Forestry Land in Vietnam: Did It Cause the Expansion of Forests in the Northwest? Forest Policy and Economics, 2, 1-11. http://dx.doi.org/10.1016/S1389-9341(00)00041-1

[41] Saxena, N.C. (2003) Livelihood Diversification and Non-Timber Forest Products in Orissa: Wider Lessons on the Scope for Policy Change? Overseas Development Institute, London.

[42] Gu, H., Jiao, Y. and Liang, L. (2012) Strengthening the Socio-Ecological Resilience of Forest Dependent Communities: The Case of the Hani Rice Terrace in Yunnan, China. Forest Policy and Economics, 22, 53-59. http://dx.doi.org/10.1016/j.forpol.2012.04.004

[43] Koy, R. and Sasaki, N. (2013) Assessment of Local Livelihood of Forest-Dependent Communities in Cambodia. International Journal of Environmental and Rural Development, 4, 63-68.

[44] Fox, J., Bushley, B.R., Dutt, S. and Quazi, S.A. (2007) Making Conservation Works: Linking livelihoods and Protected Areas in Bangladesh, East-West Center. USA and Nishorgo Program of Bangladesh Forest Department, Dhaka.

[45] Akhter, S., Faisal, A.M., Nath, T.K. and Jashimuddin, M. (1997) Impact of Forest Based Cottage Industry on Rural Development of Bangladesh: The Case of Fatickchhaari Thanaunder Chittagong District. Chittagong University Studies, Part II: Science, 21, 81-86.

[46] Alamgir, M., Jashimuddin, M. and Bhuiyan, M.A.R. (2005) Employment Generation and Economics of Cane Based Furniture Enterprises of Chittagong, Bangladesh. Journal of Bamboo and Rattan, 4, 279-291. http://dx.doi.org/10.1163/156915905774309982

[47] Khan, N.A. and Rashid, A.Z.M.M. (2006) A Study on the Indigenous Medicinal Plants and Healing Practices in Chittagong Hill Tracts (Bangladesh). African Journal of Traditional, Complementary and Alternative medicines, 3, 37-47. http://dx.doi.org/10.4314/ajtcam.v3i3.31165

[48] Miah, D. and Rahman, L. (2002) Status of Cane-Based Cottage Industries in Urban and Semi-Urban Areas of Chittagong, Bangladesh. Journal of Bamboo and Rattan, 1, 251-261. http://dx.doi.org/10.1163/156915902760184295

[49] Nath, T.K., Uddin, M.B. and Ahmed, M. (2000) Role of Bamboo Based Industry in Economic Uplift of Rural Poor: A 
Case from Rural Bangladesh. The Malaysian Forester, 63, 98-105.

[50] Geres (2007) Efficient Cook Stoves to Mitigate Global Warming and Contribute to Poverty Alleviation in Cambodia. Phnom Penh, Cambodia.

[51] Nijaguna, B. (2002) Biogas Technology. New Age International (P) Ltd., New Delhi.

[52] Katuwal, H. and Bohara, A.K. (2009) Biogas: A Promising Renewable Technology and Its Impact on Rural Households in Nepal. Renewable \& Sustainable Energy Reviews, 13, 2668-2674. http://dx.doi.org/10.1016/j.rser.2009.05.002 
Scientific Research Publishing (SCIRP) is one of the largest Open Access journal publishers. It is currently publishing more than 200 open access, online, peer-reviewed journals covering a wide range of academic disciplines. SCIRP serves the worldwide academic communities and contributes to the progress and application of science with its publication.

Other selected journals from SCIRP are listed as below. Submit your manuscript to us via either submit@scirp.org or Online Submission Portal.
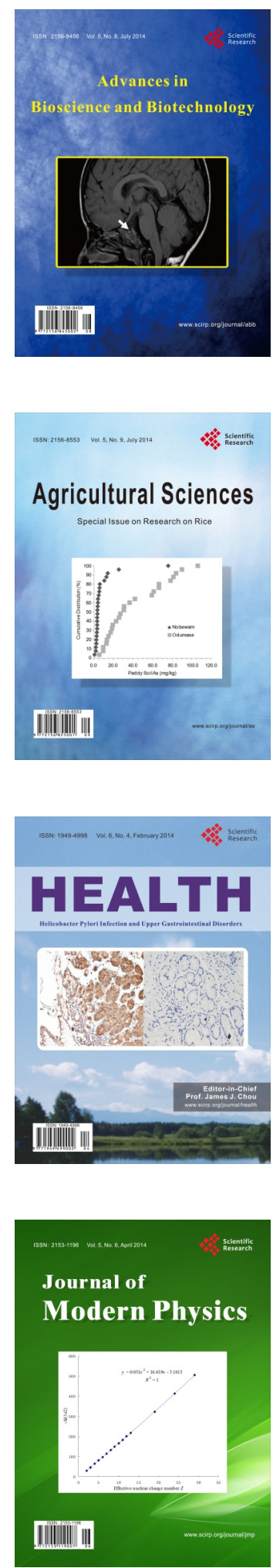
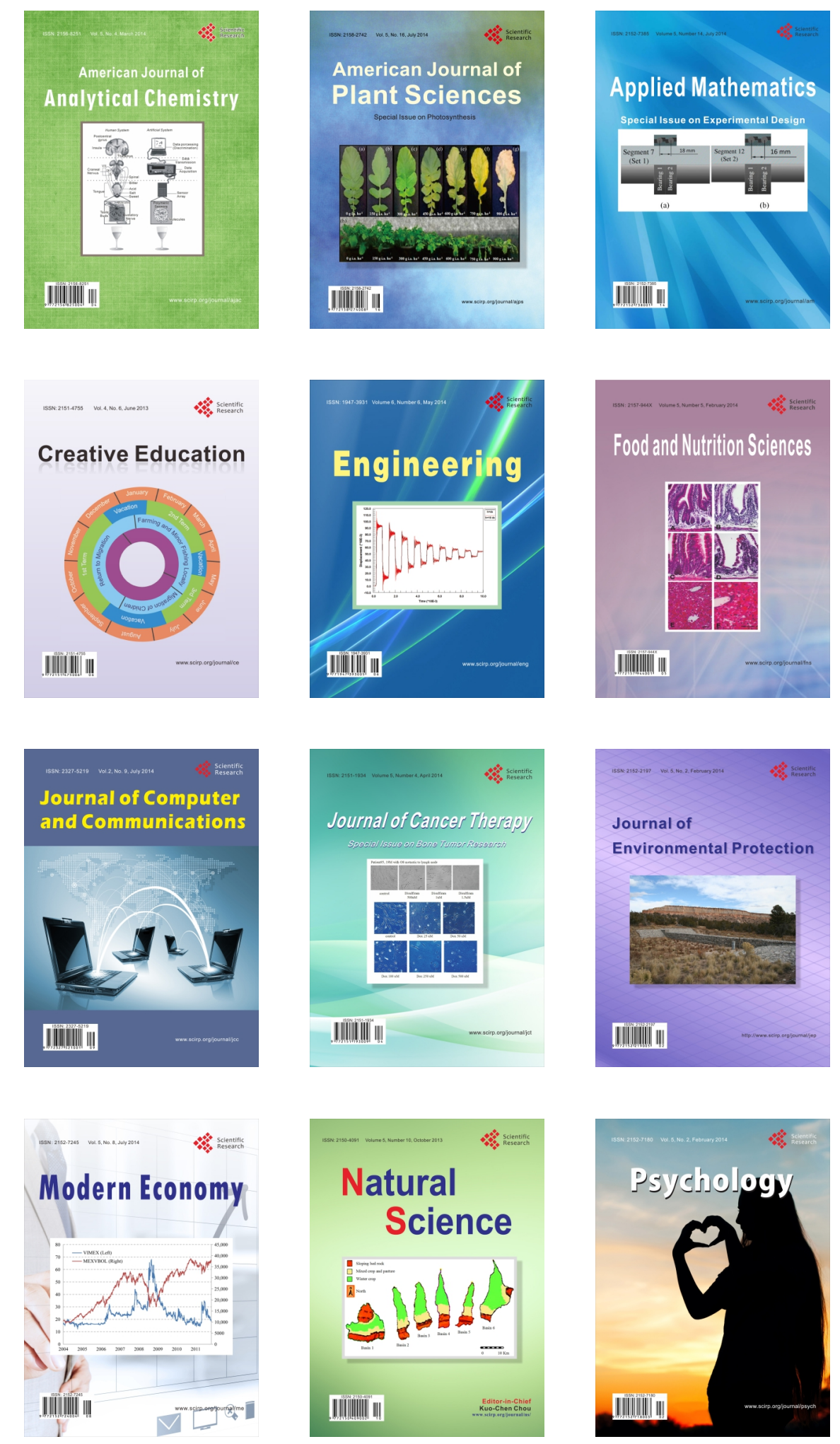